\title{
COMPARATIVE EFFICACY OF GARLIC (ALLIUM SATIVUM) AND BLACK CUMIN (NIGELLA SATIVA) AS GROWTH PROMOTERS IN BROILERS
}

\author{
P. Jha ${ }^{1}$, N. Singh ${ }^{2}$, R.Sah ${ }^{3}$, J.Yadav $^{4}$, S.S. Jha ${ }^{5}$
}

\begin{abstract}
A study was conducted to determine the comparative effect of feeding different levels of garlic and black cumin on growth, feed consumption, feed efficiency and carcass characteristics of Hubbard broiler. Two hundred fifty two Hubbard chicks having uniform body weight were randomly allocated into seven dietary treatments with three replications. The isoproteinous and isocaloric formulated standard starter, grower, and finisher diets were supplemented for 6 weeks with different levels of freshly ground dry garlic and black cumin seeds in order of $T_{1}$-control, $T_{2^{-}}-0.25 \%$ garlic, $T_{3^{-}}-0.5 \%$ garlic, $T_{4^{-}}$ $0.75 \%$ garlic, $T_{5^{-}} 0.25 \%$ black cumin, $T_{6^{-}} 0.5 \%$ black cumin, and $T_{7^{-}} 0.75 \%$ black cumin, respectively. The results showed significantly higher cumulative weekly live body weight, body weight gain and feed conversion ratio for broiler fed diet supplemented with $0.5 \%$ garlic, followed by diet supplemented with $0.5 \%$ black cumin. There was no significant effect of different levels of garlic and black cumin supplementation in diet on carcass characteristics. Furthermore, there was minimum gross expenditure in broiler diet supplemented with $0.25 \%$ garlic and maximum in broiler diet supplemented with $0.75 \%$ black cumin. However, there was highest gross income and net profit in broiler diet supplemented with $0.5 \%$ garlic, followed by broiler diet supplemented with $0.5 \%$ black cumin. It is therefore, concluded that inclusion of garlic or black cumin in the broiler rations may be used for economical and efficient production of broilers.
\end{abstract}

Key words: Broiler, black cumin, feed efficiency, garlic

\section{INTRODUCTION}

Poultry keeping has been an important source of income to many households in Nepal. There is growing awareness of nutritive value of meat and eggs among people. Poultry products (meat and egg) are a good source of food with high biological value. Therefore, poultry keeping is becoming an important enterprise in both the urban and rural areas of Nepal (Bhurtel and Shah, 2000). Chicken contributes about $14.50 \%$ of total meat production in the country and $98.52 \%$ of the total egg production (MoAD, 2011/12). These data indicate the increasing trend of poultry production in Nepal.

Current studies look after natural growth promoters to enhance growth rate and to improve feed efficiency, so as to reduce the production cost of the meat. In the past, the major growth promoters added to the feed of broilers were antibiotics. But because of their residues and subsequent occurrence of antibiotic resistantbacteria (Lee et al., 2004; Guler et al., 2006), there is great interest in

\footnotetext{
1 Prabhat Jha, Livestock Development Officer, DLS, Harihar Bhawan Email: prabhatjha50@gmail.com

${ }^{2}$ Namrata Singh, Livestock Development Officer, MoAD, Singh Durbar.

${ }^{3}$ Ramashish Sah, Assistant Professor , IAAS, Rampur

4 Jagat Lal Yadav, Professor , IAAS, Rampur

${ }^{5}$ Shyam Shankar Jha, Associate Professor, IAAS, Rampur
} 
developing natural alternatives to antibiotic growth promoters. Various herbal products are being used as growth promoters in the poultry rations like garlic (Ahmad, 2005) and black cumin (Ihsan, 2003). Such herbal products have not yet been reported to contain cross resistance to pathogens and residual effect in tissues. Garlic supplements in broiler chicken have been recognized for their strong stimulating effect on the immune system and the very rich aromatic oils enhance digestion of birds (Gardzielewska et al., 2003). Nigella sativa (black seed or black cumin) is a small aromatic black seed which contains the essential fatty acid linoleic acid which is important for obtaining maximum body weight (Salehal- Jassir, 1992).

The present work was aimed at knowing the effect of garlic (Allium sativum) and black cumin (Nigella sativa) on the growth performance, carcass characteristics and economics of broiler production.

\section{OBJECTIVES}

\section{GENERAL OBJECTIVE}

To determine the effect of garlic (Allium sativum) and black cumin (Nigella sativa) on the growth performance, carcass characteristics and economics of broiler production.

\section{SPECIFIC OBJECTIVES}

To determine weekly cumulative live weight and weight gain of broilers fed diet supplemented with garlic (Allium sativum) and black cumin (Nigella sativa).

0 To evaluate weekly and daily feed consumption and feed conversion ratio of broilers fed diet supplemented with garlic (Allium sativum) and black cumin (Nigella sativa).

0 To determine carcass characteristics and economics of broiler production over feed cost.

\section{MATERIALS AND METHODS}

This study was carried out at Institute of Agriculture and Animal Science (IAAS) Livestock Farm, Rampur, Chitwan during November, 2012 to January, 2013. The objective of the study was to determine the effect of feeding different levels of garlic and black cumin on growth performance, feed intake, feed efficiency, carcass characteristics and economics of broiler production. Day old Hubbard F15 broiler chicks were group brooded using an electric battery brooder for 7 days, and were fed on pre-experimental standard starter ration before the actual experiment began. A total of 252, 7-day-old chicks of Hubbard broiler were allocated randomly to 7 different treatments with 36 chicks in each treatment. The experiment was designed in a completely randomized design with 3 replicates of each treatment. Each replication had 12 birds. Broilers were fed isoproteinous and isocaloric formulated broiler standard starter, grower and finisher diets (basal ration) supplemented with three different levels of freshly ground dry garlic and black cumin seeds. The dietary treatments were thus set as $T_{1}$ (control) $=$ basal ration, $\mathrm{T}_{2}=$ basal ration $+0.25 \%$ garlic, $\mathrm{T}_{3}=$ basal ration $+0.5 \%$ garlic, $\mathrm{T}_{4}=$ basal 
ration $+0.75 \%$ garlic, $\mathrm{T}_{5}=$ basal ration $+0.25 \%$ black cumin, $\mathrm{T}_{6}=$ basal ration + $0.5 \%$ black cumin, and $\mathrm{T}_{7}=$ basal ration $+0.75 \%$ black cumin.

The broiler birds were raised up to $6^{\text {th }}$ week of age. The experimental birds were fed ad libitum an experimental ration with or without supplementation of garlic and black cumin. The experimental units were kept on a deep litter system in separate pens. The pens were thoroughly cleaned, white washed and disinfected before putting the experimental chick into these. All the birds were provided similar management conditions like floor space, temperature, relative humidity, ventilation and light.

The chicks were vaccinated against Litchi heart disease, Newcastle disease and infectious bursal disease. The data of weekly average body weight, weight gain and feed consumption were recorded and utilized to calculate feed efficiency for until sixth week. Feed costs of different experimental diets were calculated. At the end of six weeks of experimental period, one bird from each replication was slaughtered. The weight of each carcass was recorded and dressing percentage was calculated on the basis of dressed meat including giblets and skin. After evisceration, the heart, liver, gizzard, and abdominal fat of the slaughtered birds were taken out and weighed for their absolute weight. The data thus obtained were used for the calculation of (a) dressing percentage (\%) (Dress weight of bird/Live weight of bird) $\times 100$ ) (b) relative weight of (i) heart (ii) liver (iii) gizzard and (iv) abdominal fat. After evisceration, relative weights (g) [(weight of organ/live body weight) $X$ 100] of various internal organs such as liver, heart, gizzard, and abdominal fat of the slaughtered bird were recorded.

The data thus collected on weight gain, feed consumption, feed conversion ratio, dressing percentage and relative weights of heart, gizzard, liver, and abdominal fat were subjected to the analysis of variance (ANOVA) technique in completely randomized design. The differences in the means were compared by the Duncan's Multiple Range Tests using computer program MSTAT-C basic version 1.3 (1975).

\section{RESULTS AND DISCUSSIONS}

Birds fed $0.5 \%$ garlic supplemented ration gained significantly $(p<0.05)$ highest live weight $(2277.12 \mathrm{~g})$ among the treated groups which was statistically similar with live weight $(2244.59 \mathrm{~g})$ in broiler fed ration supplemented with $0.5 \%$ black cumin and significantly lowest body weight $(2179.54 \mathrm{~g})$ was recorded in control group without any supplementation with garlic or black cumin (Table 1). Similar results were also observed for daily live weight gain. Statistical analysis of the data revealed that the supplementation of garlic and black cumin in the broiler rations did not exhibit any significant effect on the feed consumption among birds of various treatment groups when compared to the control group (Table 1). The birds supplemented with $0.5 \%$ garlic utilized their feed significantly $(p<0.05)$ and more efficiently among the treatment groups.

These results are in close agreement with the findings of Kumar et al (2010), Mahmood et al (2009), Songsang et al (2008) and Ahmad (2005). Mahmood et al. (2009) reported that the supplementation of garlic and black cumin in the broiler ration significantly $(p<0.05)$ improved the weight gain, live weight and the feed 
conversion ratio. Ahmad (2005) reported higher weight gain in broilers fed rations supplemented with garlic. Siddig and Abdelati (2001) reported higher weight gain in broilers fed ration containing black cumin. The improvement in weight gain may be due to the action of allicin (an antimicrobial substance found in garlic), which inhibits the growth of pathogenic bacteria and aflatoxin producing fungi (Meraj, 1998). The improvement in weight gain using black cumin in rations may be due to the ethyl ether extracts of Nigella sativa that inhibits growth of intestinal bacteria such as S. aureus and E. coli as reported by Hanafy and Hatam (1991). It contains the essential fatty acid linoleic acid which is important for obtaining maximum body weight (Saleh-al- Jassir, 1992).

Table1. Showing growth performance and feed conversion ratio in broilers supplemented with different levels of garlic and black cumin from 1to 6 weeks of age.

\begin{tabular}{llllll}
\hline Treatments & $\begin{array}{l}\text { Initial live } \\
\text { weight (g) }\end{array}$ & $\begin{array}{l}\text { Final live } \\
\text { weight (g) }\end{array}$ & $\begin{array}{l}\text { Daily live } \\
\text { weight gain (g) }\end{array}$ & $\begin{array}{l}\text { Total feed } \\
\text { consumption (g) }\end{array}$ & $\begin{array}{l}\text { Feed } \\
\text { conversion } \\
\text { ratio }\end{array}$ \\
\hline Basal ration (B.R.) & 135.03 & $2179.54^{\mathrm{c}}$ & $58.41^{\mathrm{c}}$ & 4244.50 & $2.02^{\mathrm{a}}$ \\
B.R.+ 0.25\%G & 135.03 & $2182.36^{\mathrm{c}}$ & $58.49^{\mathrm{c}}$ & 4146.11 & $1.97^{\mathrm{b}}$ \\
B.R. $+0.50 \% \mathrm{G}$ & 135.03 & $2277.12^{\mathrm{a}}$ & $61.20^{\mathrm{a}}$ & 4210.43 & $1.91 \mathrm{c}$ \\
B.R. $+0.75 \% \mathrm{G}$ & 135.03 & $2210.28^{\mathrm{bc}}$ & $59.29^{\mathrm{bc}}$ & 4148.20 & $1.95^{\mathrm{bc}}$ \\
B.R.+ 0.25\%BC & 135.03 & $2204.03^{\mathrm{bc}}$ & $59.11^{\mathrm{bc}}$ & 4286.95 & $2.02^{\mathrm{a}}$ \\
B.R.+ 0.50\%BC & 135.03 & $2244.59^{\mathrm{ab}}$ & $60.27^{\mathrm{ab}}$ & 4265.83 & $1.97^{\mathrm{b}}$ \\
B.R. $+0.75 \% \mathrm{BC}$ & 135.03 & $2218.33^{\mathrm{bc}}$ & $59.52^{\mathrm{bc}}$ & 4242.22 & $1.98^{\mathrm{ab}}$ \\
F value & & $5.238^{* *}$ & $5.238^{* *}$ & $2.321 \mathrm{~ns}$ & $9.094^{* *}$ \\
Probability & & $<0.01$ & $<0.01$ & $>0.05$ & $<0.01$ \\
CV\% & & 1.18 & 1.26 & 1.49 & 1.11 \\
SEM & & 8.62 & 0.25 & 16.23 & 0.01 \\
LSD (P<0.05) & & 45.88 & 1.310 & 110.2 & 0.3916 \\
\hline
\end{tabular}

Means in a column with different superscript differ significantly by DMRT ( $\mathrm{p}<0.05)$, Where $\mathrm{G}=$ garlic, $\mathrm{BC}=$ black cumin, CV = Coefficient of variation, SEM = Standard error of mean, $\mathrm{LSD}=$ Least significant difference, ns=non significant, ${ }^{*},{ }^{* *}=$ Significant at 0.05 and 0.01 probability levels respectively.

\section{CARCASS CHARACTERISTICS}

Statistical analysis of the data did not show any difference $(p>0.05)$ between the dressing percentages of the birds of different treatment groups (Table 2). The relative weight of gizzard, liver, heart, giblet and abdominal fat were also statistically non significant among all treatment groups with or without supplementation of garlic or black cumin (Table 2).

These findings are well supported by the findings of Esmail (2012), Mahmood et al (2009) and Ahmad (2005) who reported a non-significant effect on broiler dressing percentage, relative heart, liver, gizzard and giblet weight values due to the inclusion of garlic or black cumin in the diet of broilers. 
Table 2. Dressing percentages, relative weight of giblet (gizzard, liver and heart) and abdominal fat of broilers supplemented with different levels of garlic and black cumin from 1 to 6 weeks of age.

\begin{tabular}{|c|c|c|c|c|c|c|}
\hline Treatment & Dressing \% & $\begin{array}{c}\text { Gizzard weight } \\
\%\end{array}$ & $\begin{array}{c}\text { Liver weight } \\
\%\end{array}$ & $\begin{array}{c}\text { Heart } \\
\text { weight \% }\end{array}$ & $\begin{array}{c}\text { Giblet } \\
\text { weight \% }\end{array}$ & $\begin{array}{c}\text { Abdominal } \\
\text { fat } \%\end{array}$ \\
\hline $\begin{array}{l}\text { Basal ration } \\
\text { (B.R.) }\end{array}$ & 76.99 & 2.13 & 3.09 & 0.82 & 6.04 & 1.19 \\
\hline B.R. $+0.25 \% G$ & 76.36 & 2.33 & 2.72 & 0.80 & 5.85 & 0.77 \\
\hline B.R. $+0.50 \% G$ & 77.87 & 2.32 & 2.71 & 0.81 & 5.84 & 0.88 \\
\hline B.R. $+0.75 \% G$ & 77.74 & 2.39 & 3.02 & 0.95 & 6.36 & 1.03 \\
\hline $\begin{array}{c}\text { B.R.+ } \\
0.25 \% \text { BC }\end{array}$ & 77.40 & 2.31 & 2.97 & 0.87 & 6.15 & 1.08 \\
\hline $\begin{array}{c}\text { B.R.+ } \\
0.50 \% \mathrm{BC}\end{array}$ & 78.50 & 2.32 & 2.77 & 0.81 & 5.91 & 0.97 \\
\hline $\begin{array}{c}\text { B.R.+ } \\
0.75 \% \text { BC }\end{array}$ & 78.47 & 2.00 & 2.97 & 0.87 & 5.83 & 1.29 \\
\hline F value & $0.889 \mathrm{~ns}$ & $0.661 \mathrm{~ns}$ & $0.365 \mathrm{~ns}$ & $0.469 \mathrm{~ns}$ & $0.284 \mathrm{~ns}$ & $2.291 \mathrm{~ns}$ \\
\hline Probability & $>0.05$ & $>0.05$ & $>0.05$ & $>0.05$ & $>0.05$ & $>0.05$ \\
\hline $\mathrm{CV} \%$ & 1.84 & 13.20 & 15.31 & 16.11 & 10.81 & 19.13 \\
\hline SEM & 0.31 & 0.06 & 0.09 & 0.03 & 0.13 & 0.05 \\
\hline LSD $(P<0.05)$ & & - & - & - & - & - \\
\hline
\end{tabular}

Where, $\mathrm{G}=$ garlic, $\mathrm{BC}=$ black cumin, $\mathrm{CV}=$ Coefficient of variation, $\mathrm{SEM}=$ Standard error of mean, $\mathrm{LSD}=$ Least significant difference, $\mathrm{ns}=$ non significant at 0.05 probability level.

\section{BENEFIT COST (B:C) RATIO}

Maximum gross income (Rs.330.60) was obtained from broiler diet supplemented with $0.5 \%$ garlic, followed by (Rs.325.52) broiler diet supplemented with $0.5 \%$ black cumin (Table 3). Minimum gross income (Rs. 316.10) was obtained from control group diet without supplementation with garlic or black cumin. Other treatment groups obtained gross income in between Rs. 316.10 and Rs. 330.60. Similarly, maximum net income (Rs.77.54) was obtained from broiler diet supplemented with $0.5 \%$ garlic followed by (Rs.68.83) from broiler diet supplemented with $0.5 \%$ black cumin. Minimum net income (Rs.62.35) was obtained from broiler diet supplemented with $0.75 \%$ black cumin. Other treatment groups obtained net income in between Rs. 62.35 and Rs.77.54. Similarly, highest benefit cost ratio (1.30) was obtained from broiler diet supplemented with $0.5 \%$ garlic, and lowest (1.24) from broiler diet supplemented with $0.75 \%$ black cumin (Table 3 ). The results also showed that $0.5 \%$ garlic was more profitable than $0.25 \%$ and $0.75 \%$ garlic in the diet of broilers. Similarly, $0.5 \%$ black cumin was more profitable than $0.25 \%$ and $0.75 \%$ black cumin.

The findings of the above study are in line with findings of Mahmood et al (2009) and Ahmad (2005) who reported that, the birds using 0.5\% level of the garlic fetched the maximum profit in the treatment groups followed by that of $0.5 \%$ of black cumin. Increase in the profit margin of the birds fed rations containing herbal growth promoters such as garlic and black cumin may be attributed to 
better feed efficiency and live weight gain ultimately leading to higher profit margin in the broilers.

Table 3. Mean benefit cost $(\mathrm{B}: \mathrm{C})$ ratio of broiler fed diet supplemented with different levels of garlic and black cumin from 1-6 weeks of age

\begin{tabular}{|c|c|c|c|c|c|c|}
\hline Treatment & $\begin{array}{l}\text { Gross } \\
\text { expenditur } \\
\text { e (Rs) }\end{array}$ & $\begin{array}{l}\text { Gross } \\
\text { income (Rs) }\end{array}$ & $\begin{array}{l}\text { Net } \\
\text { income } \\
\text { (Rs) }\end{array}$ & $\begin{array}{l}\text { Gross income } \\
\text { over basal } \\
\text { ration(Rs.) }\end{array}$ & $\begin{array}{l}\text { Net income } \\
\text { over basal } \\
\text { ration(Rs.) }\end{array}$ & $\begin{array}{l}\text { Benefit } \\
\text { cost } \\
(B: C) \\
\text { ratio }\end{array}$ \\
\hline $\begin{array}{l}\text { Basal ration } \\
\text { (B.R.) }\end{array}$ & 252.25 & 316.10 & 63.85 & 0.00 & 0.00 & 1.25 \\
\hline B.R. $+0.25 \%$ G & 249.19 & 316.53 & 68.58 & 0.43 & 4.73 & 1.27 \\
\hline B.R. $+0.50 \% G$ & 253.05 & 330.60 & 77.54 & 14.50 & 13.69 & 1.30 \\
\hline B.R. $+0.75 \%$ G & 251.68 & 320.45 & 68.75 & 4.35 & 4.90 & 1.27 \\
\hline $\begin{array}{l}\text { B.R.+ } \\
0.25 \% \mathrm{BC}\end{array}$ & 256.36 & 319.58 & 63.21 & 3.48 & -0.64 & 1.25 \\
\hline $\begin{array}{l}\text { B.R.+ } \\
0.50 \% \mathrm{BC}\end{array}$ & 257.69 & 326.52 & 68.83 & 10.42 & 4.98 & 1.27 \\
\hline $\begin{array}{l}\text { B.R. }+ \\
0.75 \% \text { BC }\end{array}$ & 259.54 & 321.90 & 62.35 & 5.80 & -1.50 & 1.24 \\
\hline
\end{tabular}

Note: Gross expenditure includes cost of feed, garlic, black cumin, chicks, vaccines, litter material, disinfectants and labour cost.

\section{CONCLUSIONS}

From the results of this experiment, it can be concluded that broiler diet can be successfully supplemented with $0.5 \%$ garlic or $0.5 \%$ black cumin as growth promoter for better growth performance, feed efficiency and profitability without any adverse effect on the carcass characteristics.

\section{REFERENCES}

Ahmad, S. 2005. Comparative efficiency of garlic, turmeric and black cumin as growth promoter in broiler. M.Sc. (Hons.) Thesis, Department Poultry Sciences, University of Agriculture, Faisalabad, Pakistan.

Bhurtel, R. and B. K. P. Shah. 2000. Poultry development in Nepal constraints and potentials. Published by Winrock International Research Report Series No.45:16

Esmail, S. H. 2012. Black cumin and garlic powder in poultry diets. Source: http://www. worldpoultry.net/Broilers/Nutrition/2012/9/Black-cumin-\&-garlicpowder-in poultry diets-WP010881W.

Gardzielewska, J., K. Pudyszak, T. Majewska, M. Jakubowska and J. Pomianowski. 2003. Effect of plant-supplemented feeding on fresh and frozen storage quality of broiler chicken meat. Animal Husbandry Series of Electronic J. Polish Agric. Univ. 6(2). http://www.ejpau.media. pl/series/volume6/issue2/animal/art-12.html

Guler, T., B. Dalkilic, O. N. Ertas and M. Ciftci. 2006. The effect of dietary black cumin seeds (Nigella Sativa L.) on the performance of broilers. Asian-Aus. J. Anim. Sci. 19: $425-430$

Hanafy, M.S. and M.E. Hatem 1991. Studies on the antimicrobial activity of Nigella sativa seed (black cumin). Journal of Ethnopharmacology 34: 275-278. 
Ihsan, K. 2003. Effect of different levels of black cumin (N. sativa) seeds on the performance of broilers. M. Sc. (Hons.) Thesis, Department of Poultry Sciences, University of Agriculture, Faisalabad, Pakistan.

Kumar, S., K. C. Sharadamma, P. M. Radhakrishna. 2010. Effects of garlic active based growth promoter on growth performance and specific pathogenic intestinal microbial counts of broiler chicks. Int. J Poultry Sci. 9(3): 244-246.

Lee, K. W., H. Evarts and A. C. Beynen. 2004. Essential oils in broiler nutrition. Int. J. Poult. Sci. 3: 738-752.

Mahmood, S., M. M. Hassan, M. Alam and F. Ahmad. 2009. Comparative efficacy of Nigella sativa and Allium sativum as growth promoters in broilers. Int. J. Agric. Biol., 11: 775778.

Meraj, I. C. A. 1998. Effect of garlic and neem leaves supplementation on the performance of broiler chickens. M.Sc. Thesis, Department of Poultry Sciences, University of Agriculture, Faisalabad, Pakistan.

MoAD. 2012. Ministry of Agriculture Development, Statistical Information on Nepalese Agriculture, 2011/12.

MSTAT-C. 1975. Basic version 1.3. Michigan State University, USA.

Saleh, Al-Jassir M. 1992. Chemical composition and microflora of black cumin (Nigella sativa L.) seeds growing in Saudi Arabia. Food Chem. 45:241-245.

Siddig, R. M. and K. Abdelati. 2001. Effect of dietary vitamin A and N. sativa on broiler chicks' performance. In: Proc. of 10th Int. Conf. of Assoc. of Inst. for Trop. Vet. Med. Livestock. Community and Environment, Copenhegen, Denmark.

Songsang, A., A. Suwanpugdee, U. Onthong, R. Sompong, P. Pimpontong, S. Chotipun and W. Promgerd. 2008. Effect of Garlic (Allium sativum) Supplementation in Diets of Broilers on Productive Performance, Meat Cholesterol and Sensory Quality. Conference on International Research on Food Security, Natural Resource Management and Rural Development, University of Hohenheim, October 7-9, 2008. 